\title{
Transfer of patients in hospital units: impacts on nursing workload*
}

\author{
Transferência de pacientes em unidades hospitalares: influência \\ sobre a carga de trabalho em enfermagem \\ Traslado de pacientes en unidades hospitalarias: influencia en la carga \\ de trabajo de enfermería
}

How to cite this article:

Trovó SA, Cucolo DF, Perroca MG. Transfer of patients in hospital units: impacts on nursing workload. Rev Esc Enferm USP. 2021;55:e0327. doi: https://doi. org/10.1590/S1980-220X2020024903727

\author{
Simone Aparecida Trovó ${ }^{1}$ \\ Danielle Fabiana Cucolo ${ }^{2,3}$ \\ Márcia Galan Perroca ${ }^{1}$ \\ * Extracted from the dissertation: \\ "Rotatividade de pacientes e sua influência \\ sobre a carga de trabalho em enfermagem", \\ Programa de Pós-Graduação stricto sensu \\ em Enfermagem, Faculdade de Medicina \\ de São José do Rio Preto, 2019. \\ 1 Faculdade de Medicina de São José do \\ Rio Preto, Programa de Pós-Graduação em \\ Enfermagem, São José do Rio Preto, SP, Brazil. \\ 2 Universidade Federal de São Carlos, \\ Programa de Pós Graduação em \\ Enfermagem, São Carlos, SP, Brazil. \\ ${ }^{3}$ Pontifícia Universidade Católica de Campinas, \\ Programa de Pós Graduação de Residência \\ Multiprofissinal em Saúde, Campinas, SP, Brazil.
}

\begin{abstract}
Objective: To measure the average time spent by the nursing team in transferring patients; to compare the activities observed during the performance of this intervention with those described by the Nursing Interventions Classification and to investigate the intensity of its influence on the workload. Method: Observational study using timekeeping software conducted in two hospitals in the northwest region of the State of São Paulo. 200 patient transfers were monitored by the team using two validated instruments. Results: The average time spent by nurses on transfers ranged from 9.3 (standard deviation $=3.5$ ) to 12.2 (standard deviation $=2.5$ ) minutes and by assistants technicians between 7.1 (standard deviation $=2,8)$ and $11.0($ standard deviation $=2.2)$ minutes. 63 transfers made by nurses and 87 by assistants/technicians were considered qualified ( $\geq 70 \%$ of the score). The team expended 19.3 to $29 \%$ of the working day time in this intervention. Conclusion: The transfer of patients has an impact on the workload of the team and needs to be considered in the measurement of nursing activities for the calculation and distribution of personnel to improve the quality and continuity of care.
\end{abstract}

\section{DESCRIPTORS}

Workload; Process Assessment; Health Care; Time Management; Workflow; Nursing Staff.
Corresponding author:

Danielle Fabiana Cucolo

Rua Moacir Chagas, 41, Jd Guarani

CEP 13100-021 - Campinas, SP, Brazil

danielle.fabiana.cucolo@gmail.com
Received: 07/01/2020

Approved: 11/06/2020 


\section{INTRODUCTION}

The transfer of patients among units is a common practice in hospital units ${ }^{(1)}$. The decision to transfer them is based on the benefits related to diagnosis and/or treatment that is available in another unit, but it involves risks ${ }^{(2)}$.

Due to its complexity, it requires planning and organization of several resources, patient/family orientation and communication among professionals ${ }^{(3)}$. The standardization of actions and necessary equipment, maintenance of properly qualified personnel for transportation, the collaboration of health professionals and the effectiveness in communication during the transference contribute to minimize adverse events ${ }^{(4-5)}$.

Patients also feel the impact of these movements among units. Findings reveal that the increase in the frequency of these transfers decreases satisfaction with the care provided by nursing staff and with the hospital environment. The time to respond to nursing calls, assistance to self-care, the cordiality of the professionals and the time dedicated to other patients were shown to be impaired in these situations ${ }^{(1)}$.

To accommodate the demand, bed management sometimes needs to make a succession of transfers, organizing and relocating patients ${ }^{(4)}$. Since in-hospital transportation demands time from the nursing staff ${ }^{(3)}$, the repercussion of these movements directly affects the workload and, consequently, the number of professionals needed to meet the patients' care demands ${ }^{(6-7)}$. The nursing workload $(\mathrm{NW})$ is the product of the number of care interventions (direct and indirect) for the time dedicated by the team reflecting on the quality and results of the assistance ${ }^{(8)}$.

When the personnel calculation does not consider the team's real work demand, the overload generated can reflect on the assistance provided, and, considering the inability to perform the necessary care, it can also affect the satisfaction and health of the workers ${ }^{(7)}$. Process improvement interventions are emphasized worldwide since they positively influence the effectiveness, efficiency and safety in health care ${ }^{(9)}$. The international taxonomy of nursing interventions ${ }^{(10)}$ has guided nurses in the field of practice (elaboration of protocols, care plans, development and competence assessment, among others) and researchers in the investigation of this process. In this sense, the activities inherent to the workday, including the movement of patients entering and leaving the hospital units, need to be considered in the measurement of the load and in staff calculation ${ }^{(11)}$.

This study is part of a broader project built to investigate other factors that influence the workload, not only related to the assistance complexity, including the turnover of patients in the units, and is linked to the research group Health and Nursing Services Management (Gestão dos Serviços de Saúde e de Enfermagem - Gestsaúde). It seeks to answer the following questions: What is the average time spent by the nursing team in transferring patients performing activities in accordance with those described by the Nursing Interventions Classification (NIC) ${ }^{(10)}$ ? What is the influence of this intervention on the workload of the nursing team?
And, thus, it has as objectives: to measure the average time spent by the nursing team in the transfer of patients; to compare the activities observed during the performance of this intervention with those described by the Nursing Interventions Classification ${ }^{(10)}$ and to investigate the intensity of its influence on the workload.

\section{METHOD}

\section{Design OF STUdY}

This is a quantitative study. The observational method with timekeeping was used.

\section{SCENARIO}

One have carried out this study in four Inpatient Units (three surgical clinics and one medical-surgical) and three specialized units (adult intensive care, urgency and emergency and maternal infant) in two medium-sized hospitals, one of them a teaching hospital, located in the state of São Paulo, Brazil.

Approximately 380 transfers among units are registered at these institutions each month. This intervention is standardized in the Standard Operating Procedures (SOP), in both hospitals, and it has been used as a guide for nursing practice. There is complementarity in the activities carried out by the team in the transfer of patients according to professional skills. However, the patient's assistance complexity will determine the professional who will accompany them in the transfer process. One has observed, for the unit choice, a greater movement of patients for transfers.

\section{Selection CRITERIA}

The sample size was statistically defined as $\mathrm{N}=100$ with a power of $80 \%$ and $p \leq 0.05$. One has followed 22 members of the nursing team, who had already finished the time of work experience (90 days) and who agreed to have their care activities observed and measured during the performance of this intervention, during the day and night, in both institutions.

\section{Data collection}

In order to meet the purposes of the study, two instruments were built referring to the transference intervention and its deployment in activities for each of the professional categories (nurses and assistants/nursing technicians). The data were supplemented by applying a questionnaire addressing aspects related to age, gender, length of experience at the institution, work shift and professional qualification of the participants.

The construction started with the selection of activities related to intra-hospital transport of patients (NIC $7892)^{(10)}$ in line with the Brazilian practice scenario. Subsequently, they were grouped into categories, differentiating nurses (N) from assistants/technicians (NA/ NT): 1. Communication - orienting patient/companion (N/NA/NT); checking the new location (N/NA/NT); 
existence of medical prescription $(\mathrm{N})$; to communicate destination site $(\mathrm{N}) ; 2$. Care - assistance in the patient's needs (N/NA/NT); referral to the new unit (NA/NT); 3. Resources needed for transportation (N/NA/NT) and 4. Documentation (N/NA/NT).

The activities listed in the instruments were submitted to assessment by five doctor nurses and three clinical nurses to verify the relevance, clarity and representativeness of their content to the context of practice. $98 \%$ agreement was obtained, above $\geq 80 \%$ established in the literature ${ }^{(12)}$. The pre-test in hospital units followed this stage confirming its adequacy. The monitoring of transfers in the units took place from July 2016 to February 2017. There was a complement, for the study of the historical series, from August to October 2018.

One has used a time tracking software ${ }^{(13)}$ named Togg $l^{(14)}$ to measure the time spent on the activities. The zero moment for the transfer of the patient was the contact of the nursing professional with the destination unit to confirm the availability of the bed. The timing then followed the provision of necessary resources for the transfer, the guidance to the patient and/or family member and the nursing activities related to the preparation, transportation and accommodation of the patient in the destination bed. After the on duty shift and activities registered in the medical record, the timer was stopped.

Observation sessions took place from Monday to Friday, during the day and night. One of the researchers was communicated by telephone regarding the proximity of transfers in the units investigated. The interaction with the professional, during the development of the action, was avoided except when there was a need to clarify doubts regarding the performance of any activity.

When the nursing team was performing an activity, it was checked on the patient transfer instruments to verify if there was compliance with the activities of the NIC, and concomitantly the measurement of elapsed time.

\section{Data ANALYSIS AND TREATMENT}

The data were computed through:

- Descriptive statistics: absolute frequency and percentage for categorical variables; mean (M), standard deviation (SD), minimum and maximum values, median (MD) and quartiles (Q1-Q3) for the numerical variables;

- Chi-square test: comparison of categorical variables and, in the presence of expected values inferior to five, Fisher's exact test was used;

- Mann-Whitney test (comparison of numerical variables between two groups), Kruskal-Wallis test (comparison among three or more groups, due to the absence of normal distribution of variables) and Dunn's multiple comparison test (for significant differences).
One adopted the limit of $70 \%$ of the total score to verify the quality of the transfer process, with scores ranging from 5 to 7 for nurses and from 4 to 6 for nursing assistants and technicians. The monthly measurement of the number of activities conducted in each unit, shift and professional category was obtained by studying a three-month historical series.

To calculate the percentage of time spent on the workday, one has considered the hours worked per shift, excluding daytime and night time work breaks; where: Total time = mean admission time multiplied by the average number of admissions/category and unit; Hours (\%) = mean time of admissions converted into \% considering 5.75 hours (345 minutes) effectively worked during the day and 11 hours (660 minutes) at night.

The analysis was processed using the program The SAS System for Windows (Statistical Analysis System), version 9.2.SAS Institute Inc, 2002-2008, Cary, NC, USA assuming the significance level $\mathrm{p}<0.05$.

\section{ETHICAL ASPECTS}

The Research Ethics Committee (Opinion n ${ }^{\circ}$ 980.660/2015), the Hospital Administrator and the Nursing Manager of the investigated institutions endorsed the study. Participants accepted it by signing the Informed Consent Form (ICF) in accordance with resolution 466/12.

\section{RESULTS}

A total of 200 transfers were observed (100 performed by nurses and 100 by assistants/technicians) among the units studied, 138 (69\%) of which were performed in the Urgency and Emergency Unit $(\mathrm{N}=61$ and $\mathrm{NA} / \mathrm{NT}=$ 77), $31(16 \%)$ in the Surgical Units ( $=19$ and NA/NT = 12), 20 (10\%) in the Intensive Care Unit, exclusively by nurses. In the Maternal Infant $(\mathrm{n}=8 ; 4 \%)$ and MedicalSurgical ( $n=3 ; 1 \%$ ) Units, they were performed only by assistants and technicians. Observation opportunities occurred, predominantly, in the morning $(\mathrm{n}=102)$ and afternoon $(\mathrm{n}=90)$ shifts.

Nurses demanded, on average, $9.3(\mathrm{SD}=3.5)$ minutes in transfers performed in Urgency and Emergency and 12.2 $(\mathrm{SD}=2.5)$ minutes in the Intensive Care Unit $(\mathrm{p}<0.01)$. The time spent by assistants/technicians ranged from 7.1 (SD = 2.8) minutes in Surgical Unit 1 to $11.0(\mathrm{DP}=2.2)$ minutes in the Maternal Infant Unit. During the shifts, the greatest time required by nurses and assistants/technicians was at night - 11.1 (SD = 4.0) minutes - and afternoon - 9.7 (SD = 3.0) minutes, respectively (Table 1 ).

In the observation of patient transfers, the item Documentation was omitted by both nurses (46\%) and assistants/technicians (42\%) and 39\% of activities to assist the patient's needs (item Care) were not performed by nurses (Table 2). 
Table 1 - Average time spent (in minutes) by nurses and assistants/technicians to carry out transfers - Catanduva, SP, Brazil, 2018.

\begin{tabular}{|c|c|c|c|c|c|c|}
\hline \multirow{2}{*}{ Variable } & \multicolumn{3}{|c|}{ Nurses $(n=100)$} & \multicolumn{3}{|c|}{ Nursing Assistants/Technicians $(\mathrm{n}=100)$} \\
\hline & $M(S D)$ & Variation & Value $p$ & $M(S D)$ & Variation & Value $p$ \\
\hline \multicolumn{7}{|l|}{ Units } \\
\hline Surgical 1 & $10.1(4)$ & $4.4-15$ & $<0,01 *$ & $7.1(2.8)$ & $3.1-12.3$ & Ns* \\
\hline Surgical 2 & $9.8(2.9)$ & $6.4-13.2$ & UEU $\neq I C U^{* *}$ & $10.8(0.8)$ & $10.2-11.4$ & \\
\hline Surgical 3 & - & - & & $7.5(4.1)$ & $2.8-10.3$ & \\
\hline MSU & - & - & & 9.7(3.4) & $7.3-12.2$ & \\
\hline MIU & - & - & & $11.0(2.2)$ & $7.5-13.5$ & \\
\hline UEU & $9.3(3.5)$ & $3.3-19.2$ & & $9.2(3.2)$ & $1.3-16.3$ & \\
\hline $\mathrm{ICU}$ & $12.2(2.5)$ & $8.6-17.4$ & & - & - & \\
\hline All Units & $10.1(3.5)$ & $3.3-19.3$ & & 9.2(3.2) & $1.3-16.3$ & \\
\hline \multicolumn{7}{|l|}{ Shifts } \\
\hline Morning (M) & $9.4(3.2)$ & $3.3-19.2$ & $\mathrm{Ns}^{*}$ & $8.8(3.2)$ & $1.3-16.3$ & Ns* \\
\hline Afternoon (A) & $10.8(3.7)$ & $3.3-18.3$ & & $9.7(3.0)$ & $3.1-14.5$ & \\
\hline Night (N) & $11.1(4.0)$ & $6.4-15.4$ & & $6.7(3.7)$ & $2.8-10.3$ & \\
\hline
\end{tabular}

Note: M: Mean; SD: Standard deviation; Ns: Not significant; MSU: Medical Surgical Unit; MIU- Maternal Infant Unit; UEU: Urgency and Emergency Unit; ICU: Intensive Care Unit; Value p- *Mann Whitney test; **Kruskal-Wallis. n= 200.

Table 2 - Frequency of attendance of the scores for each item verified in the transfers made by nurses and assistants/technicians Catanduva, SP, Brazil, 2018.

\begin{tabular}{|c|c|c|c|c|}
\hline Subitems & $\begin{array}{c}\text { Communication } \\
(4 / 2)^{*} \\
N(\%)\end{array}$ & $\begin{array}{l}\text { Care } \\
(1 / 2)^{*} \\
\mathrm{~N}(\%)\end{array}$ & $\begin{array}{c}\text { Resources/transport } \\
(1 / 1)^{*} \\
\mathrm{~N}(\%)\end{array}$ & $\begin{array}{c}\text { Documentation } \\
(1 / 1)^{*} \\
N(\%)\end{array}$ \\
\hline \multicolumn{5}{|l|}{$\operatorname{Nurse}(n=100)$} \\
\hline Did not perform & - & $39(39)$ & $27(27)$ & $46(46)$ \\
\hline 1 & $1(1)$ & $61(61)$ & $73(73)$ & $54(54)$ \\
\hline 2 & $14(14)$ & - & - & - \\
\hline 3 & $34(34)$ & - & - & - \\
\hline 4 & $51(51)$ & - & - & - \\
\hline \multicolumn{5}{|l|}{ Assist/Tec $(n=100)$} \\
\hline Did not perform & $4(4)$ & $1(1)$ & 19(19) & $42(42)$ \\
\hline 1 & $21(21)$ & $18(18)$ & $81(81)$ & $58(58)$ \\
\hline 2 & $75(75)$ & $81(81)$ & - & - \\
\hline
\end{tabular}

Note: Resources/transport: Resources for transport; Assist/Tec: Assistant/Technician; *Score available on each item for Nurses/Assistants and Technicians. $n=200$.

Considering the historical series, between August and October 2018, the nursing team performed 835 transfers/ month. The mean number ranged from $13(\mathrm{SD}=3.0)$ to $378(\mathrm{SD}=47.7)$ among units and from $67(\mathrm{SD}=8.1)$ to $245(\mathrm{SD}=22.1)$ in shifts. The nurses were responsible for $210(\mathrm{SD}=12.2)$ and the assistants/technicians $625(\mathrm{SD}$ $=25.5)$ of the movements. When the total score $\geq 70 \%$ was reached, the mean time for nurses was $10.9(\mathrm{SD}=$ 3.9) minutes and for assistants/technicians $9.3(\mathrm{SD}=3.2)$ minutes (Table 3).

Regarding the mean time dedicated to patient transfers, the nursing team spent between 6.1 minutes (MedicalSurgical Unit) and 30.2 minutes (Surgical 3) with an increase percentage of 19.3 in the working day (morning) and 29 (afternoon). To reach a score $\geq 5$ (nurses) and $\geq 4$ (assistants/ technicians), the professionals spent 76.3 and 193.7 minutes, respectively (Table 4).
Table 3 - Mean distribution/month of transfers made by the nursing team per units and shifts from August to October 2018 and mean time (in minutes) according to cut in the score $70 \%-\mathrm{Ca}$ tanduva, SP, Brazil, 2018.

\begin{tabular}{lcc}
\hline Variables & $\begin{array}{c}\text { Nurses ( } \mathbf{n}=\mathbf{2 1 0}) \\
\mathbf{M}(\mathbf{S D})\end{array}$ & $\begin{array}{c}\text { Assistants/Technicians }(\mathbf{n}=\mathbf{6 2 5}) \\
\mathbf{M}(\mathbf{S D})\end{array}$ \\
\hline Units & & \\
Surgical 1 & $14(4.0)$ & $31(5.5)$ \\
Surgical 2 & $23(4.6)$ & $22(4.9)$ \\
Surgical 3 & $22(4.9)$ & $121(1.1)$ \\
Medical-Surgical & $13(3.0)$ & $19(8.9)$ \\
Maternal Infant & $13(3.0)$ & $21(6.0)$ \\
Emergency & $94(15.5)$ & $378(47.4)$ \\
Intensive Care & $31(1.7)$ & $33(2.5)$ \\
\hline Shifts & & \\
Morning & $69(13.3)$ & $153(10.7)$ \\
Afternoon & $74(5.0)$ & $227(34.5)$ \\
Night & $67(8.1)$ & $245(22.1)$ \\
\hline Score & & \\
$\geq 4$ & - & $9.3(3.2)$ \\
$\geq 5$ & $10.9(3.9)$ & - \\
\hline
\end{tabular}

Note:M: mean; SD: Standard deviation. $\mathrm{n}=835$. 
Table 4 - Total mean time (in minutes) and percentage of the workday dedicated to nursing team transfers per unit, shift and second cut in the score by $70 \%$ - Catanduva, SP, Brazil, 2018.

\begin{tabular}{|c|c|c|c|c|c|c|}
\hline \multirow{2}{*}{ Variables } & \multicolumn{2}{|c|}{ Nurses $(n=100)$} & \multicolumn{2}{|c|}{$A / T(n=100)$} & \multicolumn{2}{|c|}{ Nursing team $(n=200)$} \\
\hline & Total time & Workday (\%) & Total time & Workday $(\%)$ & Total time & Workday(\%) \\
\hline \multicolumn{7}{|l|}{ Units } \\
\hline Surgical 1 & 4.7 & - & 7.3 & - & 12 & - \\
\hline Surgical 2 & 7.5 & - & 7.9 & - & 15.4 & - \\
\hline Surgical 3 & - & - & 30.2 & - & 30.2 & - \\
\hline Medical-Surgical & - & - & 6.1 & - & 6.1 & - \\
\hline Maternal Infant & - & - & 7.7 & - & 7.7 & - \\
\hline Emergency & 29.1 & - & 115.9 & - & 145 & - \\
\hline Intensive Care & 12.6 & - & - & - & 12.6 & - \\
\hline All units & 70.7 & - & 191.7 & - & 262.4 & - \\
\hline \multicolumn{7}{|l|}{ Shifts } \\
\hline Morning & 21.6 & 6.3 & 44,9 & 13,0 & 66.5 & 19.3 \\
\hline Afternoon & 26.6 & 7.7 & 73.4 & 21,2 & 100 & 29.0 \\
\hline Night & 24.8 & 7.2 & 54.7 & 15,8 & 79.5 & 23.0 \\
\hline \multicolumn{7}{|l|}{ Score } \\
\hline$\geq 5$ & 76.3 & - & - & - & - & - \\
\hline$\geq 4$ & - & - & 193.7 & - & - & - \\
\hline
\end{tabular}

Note: A/T: Assistants/Technicians. $n=200$.

\section{DISCUSSION}

The cultural and political complexity of hospitals and their microsystems reflects on the transfer of patients among units $^{(5,15)}$. The different priorities and challenges between demand and supply of beds often generate conflicts and disagreements between the teams ${ }^{(15)}$. The bed management service suffers from these pressures and needs to negotiate schedules, assess patient needs and availability of resources deciding on the best kind of occupation ${ }^{(5)}$.

In the investigated institutions, the management of beds centralized in a service contributed to the collection of data allowing to identify the times of greatest flow of transfers through the daily analysis of the bed panel, via computerized system and, thus, it was possible to evaluate the process from the bed confirmation by the applicant to the destination unit.

Activities in accordance with those described by the $\mathrm{NIC}^{(10)}$, observed during the movement of patients, pointed out the item Documentation as the most neglected, both by nurses (46\%) and by assistants/technicians (42\%). The lack of documentation added to the on-duty shift over the phone, the restricted time for detailing information and constant interruptions, among other communication gaps, constitute barriers to be overcome in order to improve the continuity of care ${ }^{(16)}$.

In addition to prior notification by phone, it is recommended that nurses communicate with the destination unit team using standardized checklists and establishing a dialogue to analyze potential adverse events ${ }^{(17)}$. The good relationship between the teams ${ }^{(15)}$ and the effective sharing of information ${ }^{(16,18)}$ lead to safer transfers. It seems that these efforts were considered by the researched institutions. The findings did not show any communication problems between the teams during the transfer process. However, the formalization of information through the record in medical records has not yet been shown to be effective. The findings also demonstrated that nurses are not attending to the needs of transferred patients (61\% of non-compliance with the item), an activity that seems to be delegated to assistants and technicians (18\% of non-compliance with the item), which also was noticed in another study ${ }^{(17)}$.

In the investigated units, nurses spent, on average, 10.1 minutes on patient transfers and nursing technicians/assistants 9.2 minutes, totaling 19.3 minutes dedicated by the team. This total value corroborates that described in the $\mathrm{NIC}^{(10)}$ for in-hospital transportation (16-30 minutes) and also approaches 17.7 minutes pointed out by an Australian study ${ }^{(4)}$. This is not a standard time for this intervention, but of the impact it can have on the nursing workload.

The transfers made in the ICU required more nurses' time (12.2 minutes). A Canadian research identified that these movements can be considered challenging and high risk because they involve the transition of resources, technologies, transfer of information and responsibilities, and they also depend on institutional protocols and priorities ${ }^{(18)}$, which may require more time from the nurse as the process coordinator. In the Chinese reality, transfers of patients to/ from the ICU occur using standardized forms and are more specified ${ }^{(17)}$ and can be more time consuming for nurses.

These professionals also spent a significant amount of time (10.1 minutes) in Surgical Unit 1, probably due to the displacement required to use the institution's elevators. Nursing assistants/technicians spent more time (11.0 minutes) in the Maternal Infant Unit, perhaps, due to the welcome given to parturient and/or puerperal women during this movement.

To qualify the transfer of patients, that is, $\geq 70 \%$ of the total score, the nurse spent more time - 10.9 minutes - representing an increase of $7.9 \%$; while assistants/technicians demanded 9.3 minutes - an increase of $1.1 \%$. The nursing team devoted, therefore, $4.7 \%$ more of their mean working 
time. No studies were identified to compare these findings, but a recent systematic review ${ }^{(19)}$ shows worse care results when the nurse devotes less time to the patient without clarifying, however, how nurses manage the limited time of work in the face of the diverse demands of care.

Considering a historical series of 835 transfers, there was also a significant mean variation in the internal transport of patients (13-378) among the units, reflecting on the mean time dedicated by the nursing team (6.1-30.2 minutes). It is important to note that, in some units, the transfer of some categories was not registered in the period under investigation, which may explain the small numerical value found.

Analyzing the influence of this patient turnover on the team's workload, the daily percentage of use of the working days' time varied between 19.3 (morning) and 29\% (afternoon). The greater number of discharges in the morning, perhaps, justifies the greater number of movements among the units in the afternoon. The transfers made at UEU, required more time from the nursing team in relation to the other units. The transport of patients by nurses in an adult emergency room of a university hospital represented $3.4 \%$ of the working time of these professionals ${ }^{(20)}$.

The underestimated number of personnel in hospital units is directly linked to overload, since the transfer of patients is not an activity calculated for the composition of the team ${ }^{(21)}$. And, therefore, the movement of patients needs to be considered among the determining factors for measuring nursing activities, staff dimensioning and in the elaboration of work schedules ${ }^{(11)}$.

As it considers the reality of two hospitals, the time required by the nursing team and the quality of this intervention must be investigated in other contexts of practice considering the cultural differences and work dynamics. It is important to note that observational methods may cause changes in the behavior of the people observed and that changes in the organizational dynamics and in the movement of patients in the interval between the monitoring of transfers in the units and the study of the historical series may have influenced the results obtained.

In a different view from other authors, the present study sought to list the actions of the nursing team in accordance with those described in international taxonomy ${ }^{(10)}$ conducted during the transfer of patients among units and to measure the mean time spent to perform them. It became evident that, in order to qualify the patient transfer process, the nursing team needs to dedicate a greater percentage of the working day and, in this sense, nurses must consider this movement among the units to predict the calculation of personnel and suggest improvements in the process. In addition, this study can support other research on the flow of in-hospital patients by supporting nurses in the management of care and human capital.

\section{CONCLUSION}

The mean time spent by nurses on transfers ranged from $9.3(\mathrm{SD}=3.5)$ to $12.2(\mathrm{SD}=2.5)$ minutes and by nursing assistants/technicians between 7.1 $(\mathrm{SD}=2.8)$ and $11.0(\mathrm{SD}$ $=2.2)$ minutes. Documentation and assistance with patient care needs were a weak point in the process. To qualify the transfer of patients, that is, $\geq 70 \%$ of the total score, the nursing team dedicated $4.7 \%$ more of their mean working time.

The findings of this research point to a significant influence of this intervention on the workload, revealing a consumption of 19.3 to $29 \%$ of the nursing team's working time. Thus, it needs to be included in the measurement of activities for the calculation and distribution of personnel to improve the quality and continuity of care.

\section{RESUMO}

Objetivo: Mensurar o tempo médio despendido pela equipe de enfermagem na transferência de pacientes; comparar as atividades observadas, durante a realização desta intervenção, com as descritas pela Classificação das Intervenções de Enfermagem e investigar a intensidade de sua influência sobre a carga de trabalho. Método: Estudo observacional com utilização de software para cronometragem de tempo conduzido em dois hospitais da região noroeste do Estado de São Paulo. Foram acompanhadas 200 transferências de pacientes realizadas pela equipe mediante uso de dois instrumentos validados. Resultados: $\mathrm{O}$ tempo médio dedicado pelos enfermeiros nas transferências variou de 9,3(desvio padrão=3,5) a 12,2(desvio padrão=2,5) minutos e pelos auxiliares/técnicos entre 7,1(desvio padrão=2,8) e 11,0(desvio padrão=2,2) minutos. Considerou-se qualificadas ( $\geq 70 \%$ do escore) 63 transferências realizadas por enfermeiros e 87 por auxiliares/técnicos. A equipe consumiu de 19,3 a 29\% do tempo da jornada de trabalho nesta intervenção. Conclusão: A transferência de pacientes gera impacto sobre a carga de trabalho da equipe e precisa ser contemplada na mensuração das atividades de enfermagem para dimensionamento e distribuição de pessoal visando melhoraria da qualidade e continuidade do cuidado.

\section{DESCRITORES}

Carga de Trabalho; Avaliação de Processos em Cuidados de Saúde; Gerenciamento do Tempo; Fluxo de Trabalho; Recursos Humanos de Enfermagem.

\section{RESUMEN}

Objetivo: Medir el tiempo medio empleado por el equipo de enfermería en el traslado de pacientes, comparar las actividades observadas durante esta intervención con las descritas por la Clasificación de Intervenciones de Enfermería e investigar la intensidad de su influencia en la carga de trabajo. Método: Se trata de un estudio observacional realizado con un software para el registro de los tiempos y llevado a cabo en dos hospitales de la región noroeste del estado de São Paulo. El plantel realizó 200 traslados de pacientes, supervisado por dos instrumentos validados. Resultados: El tiempo medio empleado por el personal de enfermería en los traslados osciló entre 9,3 (desviación estándar=3,5) y 12,2 (desviación estándar=2,5) minutos y el de los auxiliares/técnicos entre 7,1 (desviación estándar=2,8) y 11,0 (desviación estándar $=2,2$ ) minutos. Se consideraron cualificados 63 traslados realizados por enfermeros y 87 por auxiliares/técnicos $(\geq 70 \%$ de la puntuación). El equipo consumió del 19,3 al 29\% del tiempo de la jornada laboral en esta intervención. Conclusión: El traslado de pacientes repercute en la carga de trabajo del plantel de enfermería y debe tenerse en cuenta en la medición de las actividades de enfermería para el dimensionamiento y la distribución del personal, con el objetivo de mejorar la calidad y la continuidad de los cuidados.

\section{DESCRIPTORES}

Carga de Trabajo; Evaluación de Procesos; Atención de Salud; Administración del Tiempo; Flujo de Trabajo; Personal de Enfermería. 


\section{REFERENCES}

1. Mortensen B, Borkowski N, O'Connor SJ, Patrician PA, Weech-Maldonado R. The relationship between hospital interdepartmental transfers and patient experience. J Patient Exp. 2020;7(2):263-9. https://doi.org/10.1177/2374373519836467

2. Kulshrestha A, Singh J. Inter-hospital and intra-hospital patient transfer: recent concepts. Indian J Anaesth. 2016;60(7):451-7. https:doi. org/10.4103/0019-5049.186012

3. VanFosson CA, Yoder LH, Jones TR. Patient turnover: a concept analisys. Adv Nurs Science. 2017;40(3):298-310. https://doi.org/10.1097/ ANS.0000000000000171

4. Blay N, Roche MA, Duffield C, Gallagher R. Intrahospital transfers and the impact on nursing workload. J Clin Nurs. 2017;26(2324):4822-9. https://doi.org/10.1111/jocn.13838

5. Rosenberg A, Britton MC, Feder S, Minges K, Hodson B, Chaudhry SI, et al. A taxonomy and cultural analysis of intra-hospital patient transfers. Res Nurs Health. 2018;41(4):378-88. https://doi.org/10.1002/nur.21875

6. Blay N, Duffield CM, Gallagher R, Roche M. A systematic review of time studies to assess the impact of patient transfers on nurse workload. Int J Nurs Practice. 2014;20(6):662-73. https://doi.org/10.1111/ijn.12290

7. Hughes RG, Bobay KL, Jolly NA, Suby C. Comparison of nurse staffing based on changes in unit-level workload associated with patient churn. J Nurs Manag. 2015;23(3):390-400. https://doi.org/10.1111/jonm.12147

8. Alghamdi MG. Nursing workload: a concept analysis. J Nurs Manag. 2016;24(4):449-57. https://doi.org/10.1111/jonm.12354

9. Van Leijen-Zeelenberg JE, Elissen AMJ, Grube K, Van Raak AJA, Vrijhoef HJM, Kremer B, et al. The impact of redesigning care processes on quality of care: a systematic review. BMC Health Serv Res. 2016;16:19. https://doi.org/10.1186/s12913-016-1266-0

10. Bulechek GM, Butcher HK, Dochterman JM, Wagner CM. Classificação das intervenções de enfermagem (NIC). $6^{a}$ ed. Oxford: Elsevier; 2016

11. Park SH, Weaver L, Mejia-Johnson L, Vukas R, Zimmerman J. An integrative literature review of patient turnover in inpatient hospital settings. West J Nurs Res. 2016;38(5):629-55. https://doi.org/ 10.1177/0193945915616811

12. Polit DF, Beck CT. Fundamentos de pesquisa em enfermagem: avaliação de evidências para a prática da enfermagem. $9^{a}$ ed. Porto Alegre: Artmed; 2019.

13. Catipon Jr. JB, Infante EJT. Time tracking technology [Internet]. 2012 [cited 2019 Feb 26]. Available from: http://www.google.com/patents/ US20120065932

14. Toggl: Insanely simple time tracking [Internet]. [s.d.] [cited 2019 Feb 26]. Available from: https://www.toggl.com/

15. Germack HD, Fekieta R, Britton MC, Feder SL, Rosenberg A, Chaudhry SI. Cooperation and conflict in intra-hospital transfers: a qualitative analysis. Nurs Open. 2020;7(2):634-41. https://doi.org/10.1002/nop2.434

16. Abraham J, Burton S, Gordon HS. Moving patients from Emergency Department to Medical Intensive Care Unit: tracing barriers and root contributors. Int J Med Inform. 2020;133:104012. https://doi.org/10.1016/j.ijmedinf.2019.104012

17. Gu X, Liu H-C, Itoh K. Inter-department patient handoff quality and its contributing factors in Chinese hospitals. Cogn Tech Work 2019; 21:133-43. https://doi-org/10.1007/s10111-018-0500-4

18. Grood C, Leigh JP, Bagshaw SM, Dodek PM, Fowler RA, Forster AJ, et al. Patient, family and provider experiences with transfers from intensive care unit to hospital ward: a multicentre qualitative study. CMAJ. 2018;190(22):E669-76. https://oi.og/10.1503/cmaj.170588

19. Twigg DE, Kutzer $\mathrm{Y}$, Jacob E, Seaman K. A quantitative systematic review of the association between nurse skill mix and nursing-sensitive patient outcomes in the acute care setting. J Adv Nurs. 2019;75(12):3404-23. https://doi.org/10.1111/jan.14194

20. Garcia E A, Fugulin FMT. Nurses' work time distribution at emergency service. Rev Esc Enferm USP. 2010;44(4):1032-8. http://doi.org/10. 1590/S0080-62342010000400025

21. Blay N, Roche M, Duffield C, Xu X. Intrahospital transfers and adverse patient outcomes: an analysis of administrative health data. J Clin Nurs. 2017;26(23-24):4927-35. https://doi.org/10.1111/jocn.13976 